\title{
ESTABLISHING AN INTRAPRENEURIAL ORIENTATION AS STRATEGY: A FRAMEWORK FOR IMPLEMENTATION
}

\author{
HANNELIZE JACOBS \& STEPHEN KRUGER (RAU)
}

This paper describes a study aimed at increasing an organisation's ability to implement a strategy for establishing an intrapreneurial orientation effectively. Establishing an intrapreneurial orientation will be treated from a strategic management point of view, with the emphasis on the implementation phase of strategic management. As such, this study seeks to integrate theory and practice from the fields of strategic management and entrepreneurship.

\section{INTRODUCTION}

Today's managers, faced with rapidly changing and fast-paced competitive environments, are challenged to manage a wide variety of discontinuities. To cope with such challenges, existing larger firms are increasingly turning to corporate entrepreneurship as a means of growth and strategic renewal (Guth \& Ginsberg 1990). The decision to adopt intrapreneurship must be considered a strategic choice (Khandwalla 1987). According to Burgelman (1983:1353-1354), this process cannot be subsumed under the traditional strategic planning approaches. Therefore, there is a need to develop a new strategic management approach for the process of corporate entrepreneurship.

Despite many years of research into strategic change, the process of strategy implementation remains poorly understood (Ginsberg 1988; Hamel \& Prahalad 1989; Reid 1989). Much of the weakness in the strategy area appears to be attributable to failures in the implementation process rather than in the development of the strategy itself (Beer, Eisenstat \& Spector 1990; Woolridge \& Floyd 1990). The necessary attention should therefore be given to the implementation of strategies.

This paper describes a research project aimed at increasing an organisation's ability to implement a strategy for establishing an intrapreneurial orientation effectively, and the organisation's ability to adapt to change. A model to manage the establishment of an intrapreneurial orientation strategically and a framework to implement such a strategy are proposed. The framework is an attempt to develop a better understanding of the implementation imperatives involved in establishing an intrapreneurial orientation.

\section{THE INTRAPRENEURIAL ORIENTATION CONSTRUCT}

Although numerous efforts have been made to point out the various dimensions of the entrepreneurial process, they have not led to any widely held consensus regarding how to characterise entrepreneurship. This has led to the building and testing of a broader theory of entrepreneurship, namely the construct of entrepreneurial orientation (Lumpkin \& Dess 1996:135).

Entrepreneurship is defined here as new entry. That is, new entry explains what entrepreneurship consists of, and entrepreneurial orientation describes how new entry is undertaken. Entrepreneurial orientation can therefore be defined as the processes, practices and decision-making activities that lead to new entry (Lumpkin \& Dess 1996:136).

In this study the question is not 'What makes a firm entrepreneurial?' but 'What makes the individuals in the firm intrapreneurial?' This question is consistent with the view outlined in the following definition of entrepreneurship/intrapreneurship as an individual behaviour as opposed to a firm behaviour:

- Entrepreneurship is a process by which individuals - either on their own or inside organisations pursue opportunities without regard to the resources they currently control (Stevenson \& Jarillo 1990:23). 
- Intrapreneurship is therefore the process by which individuals inside organisations pursue opportunities without regard to the resources they currently control.

As the entrepreneurial behaviour of individuals will take place in the existing firm, the entrepreneurial orientation will be termed intrapreneurial orientation. The five key dimensions underlying the intrapreneurial orientation are (Lumpkin \& Dess 1996:136):

- autonomy - independent action and self-direction

- innovativeness - new ideas, experimentation and creativity

- risk-taking - venturing into uncertainty and committing assets

- pro-activeness - acting in anticipation of future problems or needs

- competitive aggressiveness - strongly challenging competition to achieve entry or improve position.

\section{PROPOSED MODEL TO MANAGE THE ESTABLISHMENT OF AN INTRAPRENEURIAL ORIENTATION STRATEGICALLY}

Since no model could be found to manage the establishment of an intrapreneurial orientation, various models for the management of innovation were investigated. Struwig (1991:148) found that the categories for managing innovation compared favourably with the strategic management process as proposed by Thompson (1990:28). Based on the fit between the strategic management process and the categories for managing innovation, a model for managing the establishment of an intrapreneurial orientation strategically is proposed (see Figure 1).

Figure 1: A proposed model for managing the establishing of an intrapreneurial orientation strategically

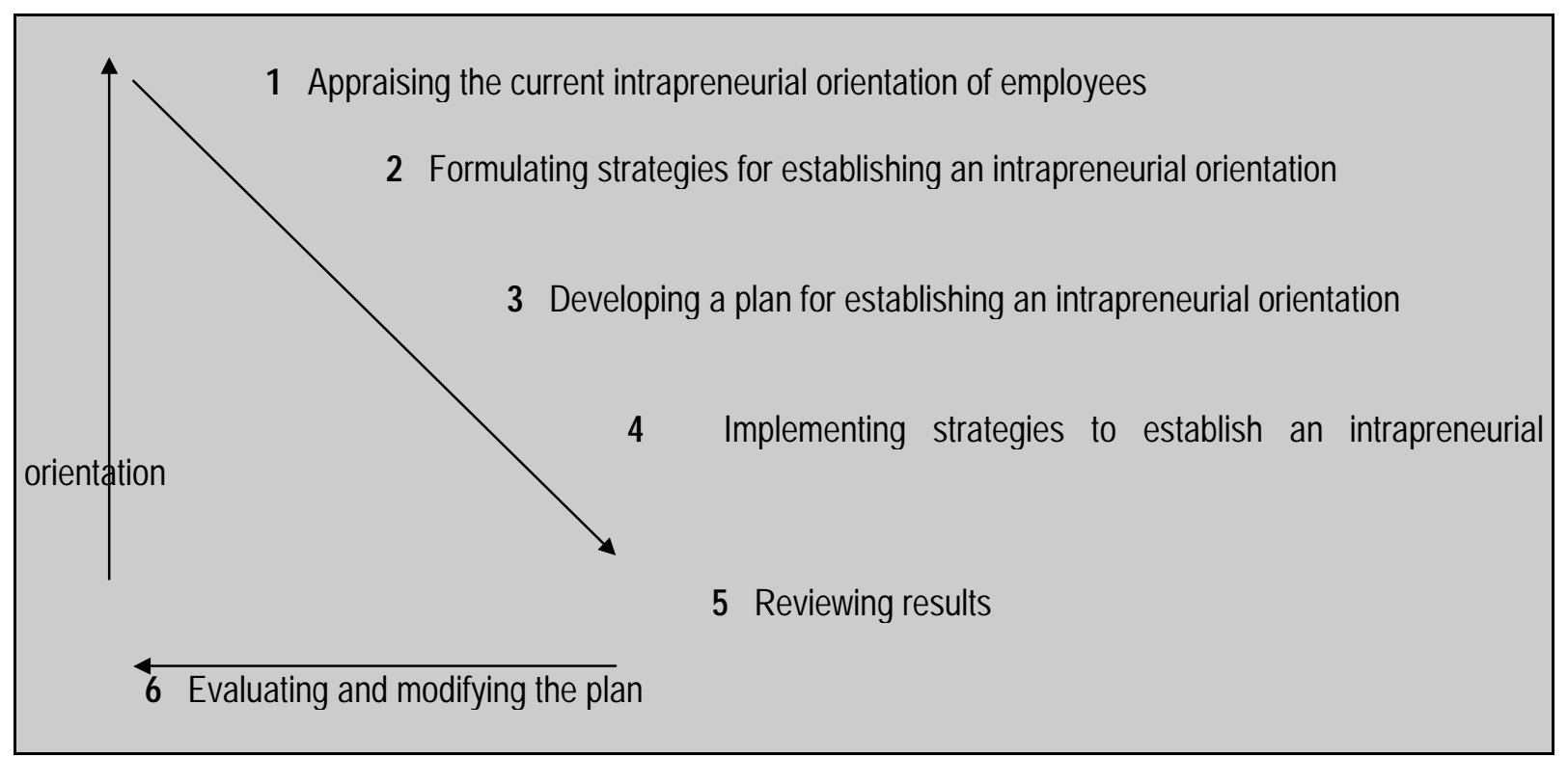

As no intrapreneurial orientation scale could be found to appraise the current intrapreneurial orientation of employees, the following item composition for an intrapreneurial orientation scale was developed based on the entrepreneurial orientation scales developed by Covin \& Slevin (1989) and Smart \& Conant (1994). 


\section{PROPOSED ITEM COMPOSITION OF AN INTRAPRENEURIAL ORIENTATION SCALE}

1. A culture of innovation

2. Ability to identify new opportunities

3. A high rate of new ideas introduction

4. An initiative, pro-active posture

5. A propensity to take risk

6. A competitive posture

7. When faced with risk, an aggressive, bold posture is adopted

8. A tendency to engage in strategic planning activities

9. An ability to persevere in making a vision a reality

\section{THE PROPOSED FRAMEWORK FOR IMPLEMENTING STRATEGIES FOR ESTABLISHING AN INTRAPRENEURIAL ORIENTATION}

The widely recognised McKinsey Seven-S model is a useful framework for addressing the formulation and implementation of business strategies (Waterman, Peters \& Phillips 1980). The McKinsey Seven$S$ categories was also used to group together the 49 characteristics that innovative firms share, to form the Innovation Quotient Inventory (IQI) test. It therefore seems like a suitable framework to use in addressing the implementation of strategies in establishing an intrapreneurial orientation.

The six S's that need to be considered along with the seventh $S$ of strategy are explained in Table 1.

Table 1: $\quad$ An explanation of the Seven-S Framework

\begin{tabular}{|l|l|}
\hline \multicolumn{2}{|c|}{ THE SEVEN-S FRAMEWORK } \\
\hline Strategy & $\begin{array}{l}\text { Plan or course of action leading to the allocation of a firm's scarce resources, } \\
\text { over time, to reach identified goals. }\end{array}$ \\
\hline Structure & $\begin{array}{l}\text { Salient features of the organisation chart (for example functional and } \\
\text { decentralised) and how the separate entities of an organisation are tied } \\
\text { together. }\end{array}$ \\
\hline Systems & Proceduralised reports and routinised processes (such as meeting formats. \\
\hline Skills & Distinctive capabilities of key personnel and the firm as a whole. \\
\hline Style & $\begin{array}{l}\text { Characterisation of how key managers behave in achieving the organisation's } \\
\text { goals; also the cultural style of the organisation. }\end{array}$ \\
\hline Staff & $\begin{array}{l}\text { 'Demographics' description of important personnel categories within the firm } \\
\text { (i.e. engineers, entrepreneurs etc.). 'Staff' is not meant in line-staff terms. }\end{array}$ \\
\hline $\begin{array}{l}\text { Shared } \\
\text { values }\end{array}$ & $\begin{array}{l}\text { The significant meanings or guiding concepts that an organisation imbues in } \\
\text { its members. }\end{array}$ \\
\hline
\end{tabular}

Source: Peters 1995:35

\section{Structure}

Khandwalla (1977:426) argues that wherever there is a strong entrepreneurial orientation there ought to be an organic orientation. This is because risk-taking managements usually seize opportunities and 
make commitments of resources before fully understanding what actions need to be taken. Unless management is flexible, the organisation will not be able to adapt itself to the evolving situation.

Covin \& Slevin (1991:18) have noted that an 'appropriate' structure for a firm with an entrepreneurial posture will often include decentralisation of decision-making authority, minimal hierarchical levels or structural layers, free-flowing communication channels, and closely integrated $R \& D$, manufacturing and marketing functions. Drucker (1994:101) has observed that "(t)he simplest organization structure that will do the job is the best one".

Structure also relates to the formation of teams. In this regard, Higgins (1996:28) advises firms that want to behave innovatively to use cross-functional and customer/supplier new-product teams, while Quinn (1985) states that large firms that are successful innovators make use of skunkworks (groups that function outside traditional lines of authority).

Structural features that should be employed in implementing strategies for establishing an intrapreneurial orientation therefore include the following:

- an overall simple and flexible structure

- decentralised decision-making authority

- minimal hierarchical levels/structural layers

- free-flowing communication channels

- closely integrated $R \& D$, manufacturing and marketing functions

- cross-functional and customer/supplier new-product teams

- skunkworks.

\section{Systems}

Systems must be designed to enable the organisation to obtain and retain staff with the skills that are needed to implement the strategic plan successfully (Thompson, Fulmer \& Strickland 1992:444), but also to assist staff to behave intrapreneurially. Such systems include the following:

- Recruitment and selection systems: The importance of recruiting and selecting managers who are capable of implementing the chosen strategy is obvious.

- Retention systems (socialisation systems): The recruitment and selection of key human resources is not enough. The retention of key people is essential (Thompson, Fulmer \& Strickland 1992:445).

- Reward systems: Reward systems, both positive and negative, can be especially useful as ways of reinforcing the values and behaviours that an organisation needs to be successful in implementing the chosen strategy. A key step in any reward system is the evaluation system used to measure an individual's performance (Thompson, Fulmer \& Strickland 1992:446).

- Control systems: Except for reward systems that can serve to motivate intrapreneurial behaviour, control systems that support entrepreneurial goals should also be implemented (Quinn 1979).

- Innovation management information systems: It is not enough just to have a management information system (MIS); part of it must be dedicated to the intrapreneurial efforts of the organisation. Higgins (1996:28) suggests the establishment of innovation management information systems (IMIS) which can help employees exchange information internally.

- Competitor analysis: Competitor analysis is another handy system for establishing an intrapreneurial organisation (Higgins 1996:29). More specifically, with respect to innovation/intrapreneurial efforts, the firm should determine competitors' SWOTs in innovation/intrapreneurial efforts; benchmark their creative activities; determine which of the major types of innovation/intrapreneurial strategies they are following and how they implement them; and learn what successes their strategies have produced. 
- Probable product/service line extensions analysis: Analysis of probable product and service line extensions should also be done (Higgins 1996:29). Signals of technological leaps should be carefully monitored.

Systems that should therefore be employed in implementing strategies for establishing an intrapreneurial orientation include the following:

- A recruitment and selection system

- A retention system

- A reward system

- Control systems

- Innovation management information systems

- Competitor analysis

- Probable product/service line extensions analysis.

\section{Skills}

Strategy researchers and consultants, Hamel \& Prahalad (1989), have identified the following two perspectives on how to implement the basic model of strategic management, namely:

- The strategic fit model suggests that a firm should adjust its strategy according to the fit between its strengths and weaknesses and the threats and opportunities in its external environment. In this model, ambitions should be trimmed to match available resources.

- The leveraging resources approach, in contrast, suggests that resources should be leveraged to achieve seemingly unreachable goals, as embodied in the term 'strategic intent'. Strategic intent encompasses not only unfettered ambition but a management process that, according to Hamel \& Prahalad (1989), includes “... focusing the organization's attention on winning; motivating people by communicating the value of the target; leaving room for individual and team contributions; sustaining enthusiasm by providing new operational definitions as circumstances change; and using intent consistently to guide resource allocations". By leveraging its resources, a firm increases its strengths or looks for ways to use them to overcome weaknesses and threats and take advantage of opportunities.

In establishing an intrapreneurial orientation, managers should acquire the skills in following the leveraging resources approach. For managers who have not yet translated a strategic intent into work group action, this may also entail learning a new skill (Higgins 1996:31).

According to Sykes \& Block (1989:161), the traditional management practice of managing functionally results in new-venture failure and should be replaced with management action supporting the intrapreneur with managerial and multidiscipline skills.

Skills that should be employed in implementing strategies for establishing an intrapreneurial orientation therefore include the following:

- Managers need to acquire skill in following the leveraging resources approach to implementing this strategy

- Managers must acquire the skill of translating strategic intent into work group action

- Intrapreneurs should be equipped with managerial and multidiscipline skills.

\section{Style}

Waldersee \& Sheather (1996) propose that the management style needed for effective implementation of a strategy should not only be consistent with the competencies required by the strategy (the socalled strategy-style matching theory as proposed by Slater (1989)), but should also include situational factors. 
To support change, management must display a concrete behaviour. Their management style needs to be consistent with steering and self-organisation. Figure 2 provides a compact overview.

\section{Figure 2: $\quad$ Management style: steering and self-organisation}

\begin{tabular}{|lll|}
\hline Steer & and & Support \\
Top-down & and & Bottom-up \\
Direct & and & Delegate \\
\hline
\end{tabular}

This means that management must: clarify frameworks, let people fill in their own responsibility, coach for results, guide toward team goals.

Source: Mastenbroek 1996:13

In order for a company to successfully employ corporate entrepreneurship in their organisation, their rules and plans must be flexible (Sykes \& Block 1989:161). Instead of enforcing standard procedures, specific ground rules should be made for each situation. Control should not be exerted against plans, but plans changed to reflect new learning.

The management style that should be employed in implementing strategies for establishing an intrapreneurial orientation therefore includes a management style that:

- $\quad$ is consistent with steering and self-organisation

- $\quad$ is consistent with the competencies required by the strategy as well as the situational factors involved

- $\quad$ reflects flexibility toward rules and plans.

\section{Staff}

Burgelman (1983:1353) stresses the importance of the middle-level "manager champion" in addition to the more familiar operational-level "product champion" role in implementing a new business idea. Kirzner (1979:104) has also expressed the view that executives, to the limited extent to which they do possess discretionary freedom of action, are able to act as entrepreneurs and implement their ideas without becoming owners themselves at all.

Traditionally, firms promoted individuals who were compatible with the organisation. In order for intrapreneurship to prosper, however, a firm must accommodate 'boat rockers' and 'doers' (Sykes \& Block 1989:161).

Higgins (1996:30) notes that staff should be provided with time for reflection. Quiet time, or time for reflection, often helps increase levels of intuition and creativity.

Staff features that should be employed in implementing strategies for establishing an intrapreneurial orientation therefore include the following:

- $\quad$ Employees on all levels of the enterprise must be given the freedom to act entrepreneurially

- $\quad$ 'Boat rockers' and 'doers' must be accommodated

- $\quad$ Staff should be provided with time for reflection.

\section{Shared values}


Shared values are closely related to the organisational culture and norms of behaviour. Aaker (1995:328) suggests that organisational culture is the central issue and that shared values, norms of behaviour, and the symbols and symbolic activities used to develop and nurture the shared values and norms form the three elements of an organisational culture. This is illustrated by Figure 3.

\section{Figure 3: Organisational culture and its three elements}

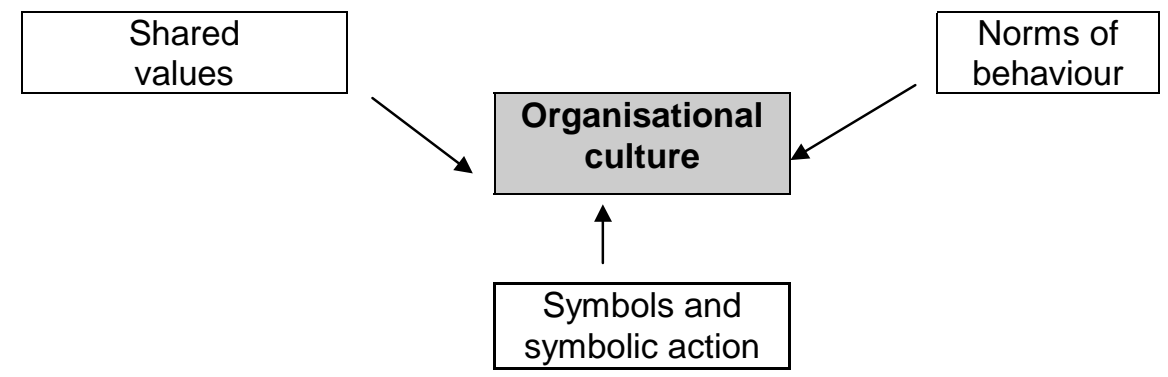

Source: Aaker 1995:329

An organisation's ability to develop and maintain an entrepreneurial orientation is contingent upon that organisation's culture (Covin \& Slevin 1991:16). Consistent with this point, Cornwall \& Perlman (1990:66) have written that "culture is a key determinant of, and the first step in fostering, entrepreneurial activity within an organization".

The strategic managers have an impact on organisational culture through both their substantive and symbolic actions (Peters \& Waterman 1982). By encouraging innovation and risk-taking, these managers help to create a culture, the norms of which in turn support an entrepreneurial orientation.

Norms that are widely shared and strongly held by members of the organisation, actively promotes the generation of new ideas and helps in implementing new approaches. Norms that are most frequently cited in innovative organisations, include risk-taking, rewards for change, openness, common goals, autonomy and belief in action (Thompson, Fulmer \& Strickland 1992:457).

To establish an intrapreneurial orientation, a creative culture is needed. This means that the organisation must be an open system where achievement is measured by what is achieved and must have a social (integrative) orientation (see Figure 4).

Actions relating to the creation of shared values that should exist when strategies for establishing an intrapreneurial orientation are implemented therefore include the following:

- Substantive and symbolic actions of managers to encourage innovation and risk-taking

- Widely shared and strongly held norms of members of the organisation for example risk-taking, openness and autonomy

- The promotion of a creative culture in the organisation by operating an open system and having a social (integrative) orientation. 
Figure 4: $\quad$ Organisational cultural model

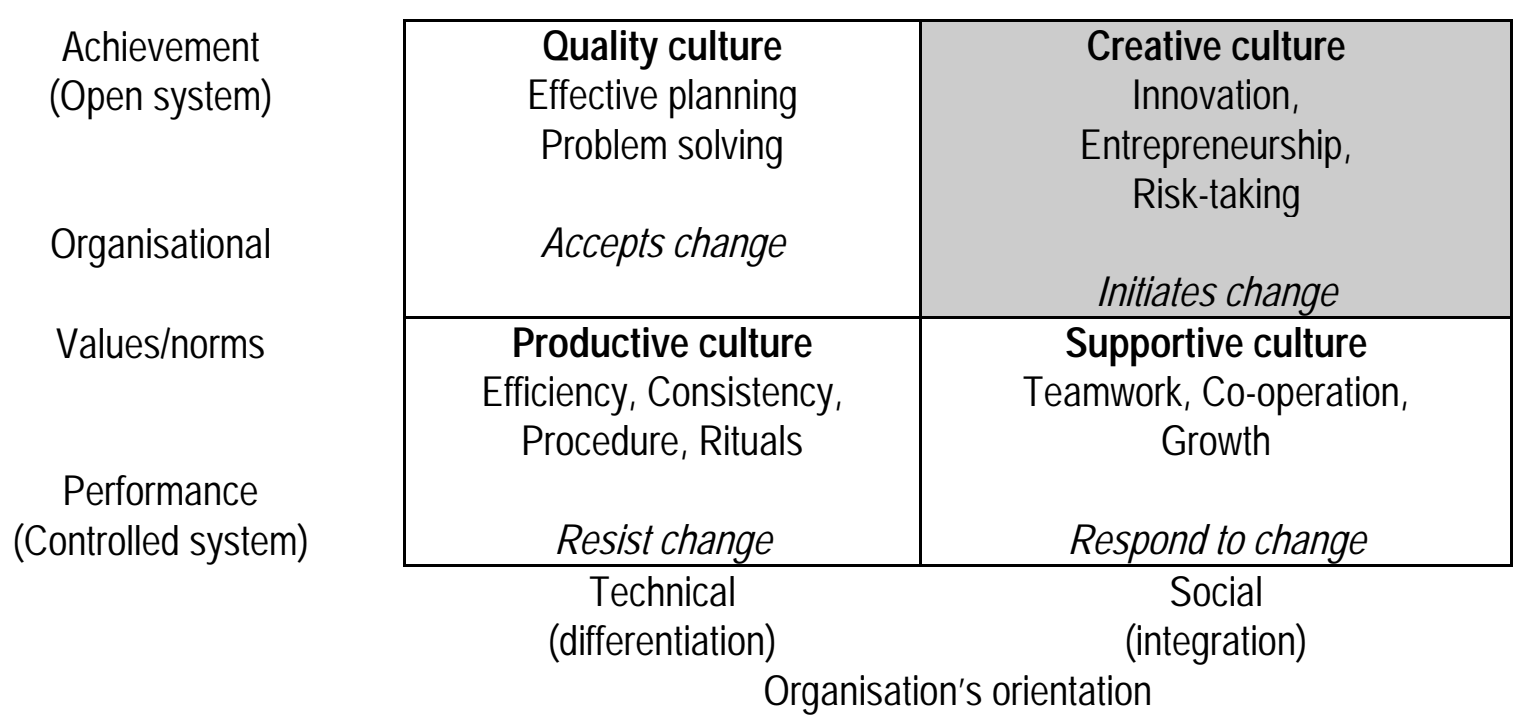

Source: Rowe et al. 1989

\section{THE EFFECTIVENESS OF IMPLEMENTATION}

Implementation effectiveness in this paper means the consistency and quality of organisational members' adoption of an intrapreneurial orientation. Klein \& Sorra (1996) have developed an integrative model of the determinants of the effectiveness of organisational implementation as depicted in Figure 5. Since innovation is one of the dimensions of an intrapreneurial orientation and related studies are "extremely rare" (Klein \& Sorra 1996:1056), the assumption is made that the model of measuring implementation effectiveness of innovation can be applied directly to measuring the implementation effectiveness of a strategy for establishing an intrapreneurial orientation.

According to Klein \& Sorra (1996), the implementation effectiveness of innovation is a function of

- the strength of an organisation's climate for implementing that innovation (in this case the strategy of establishing an intrapreneurial orientation), and

- the fit of that innovation to targeted users' values (intrapreneurial orientation).

The stronger an organisation's climate for implementing a given innovation, the greater will be the employees' use of that innovation, provided employees are committed to innovation use. The employees' commitment to innovation use indicates the limits of climate. Employees' commitment to the use of an innovation is a function of the perceived fit of the innovation to employees' values (Klein \& Sorra 1996:1062). Innovation-values fit describes the extent to which targeted users perceive use of the innovation to foster the fulfilment of their values (Klein \& Sorra 1996:1063). Innovation-values fit can be good, poor or neutral:

- Innovation-values fit is good when targeted innovation users regard the innovation as highly congruent with their high-intensity values.

- Innovation-values fit is poor when targeted innovation users regard the innovation as highly incongruent with their high-intensity values.

- Innovation-values fit is neutral when targeted users regard the innovation as either moderately congruent or moderately incongruent with their low-intensity values. 
Figure 5: Determinants and consequences of implementation effectiveness

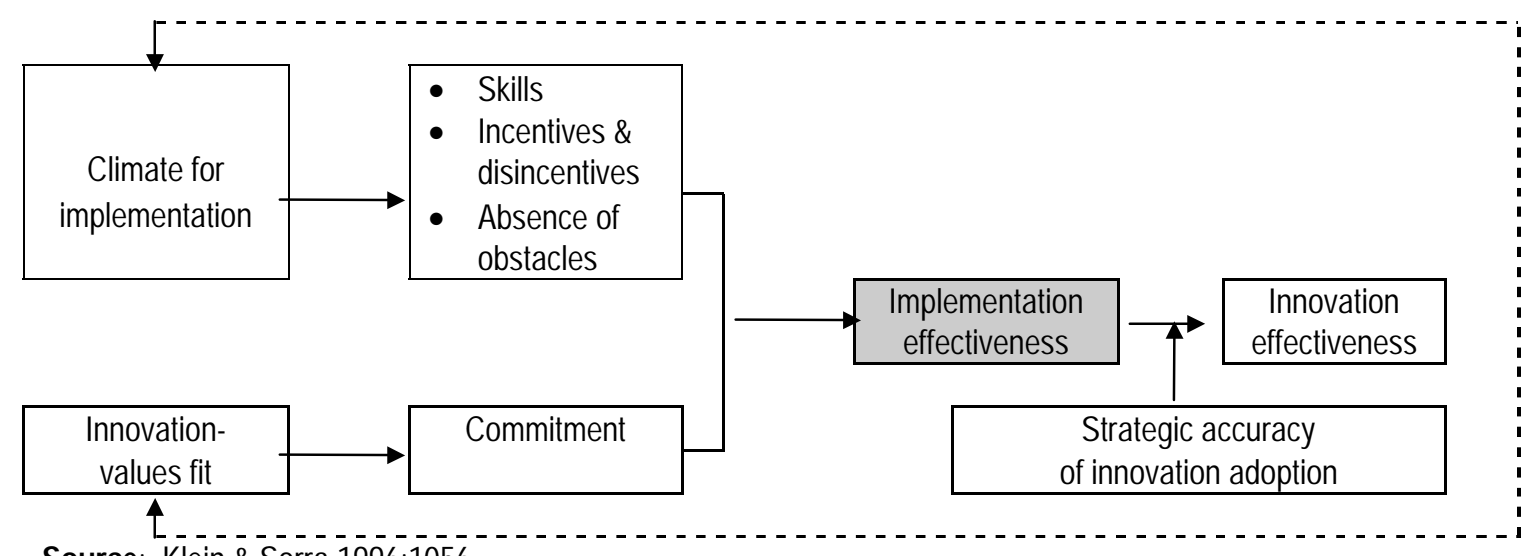

Source: Klein \& Sorra 1996:1056

The implementation effectiveness of innovation can be predicted when the influence of the implementation climate and the innovation-values fit are combined (see Table 2).

Table 2: Implementation climate and innovation-values fit: Effects on employees' affective responses and innovation use

\begin{tabular}{|c|c|c|c|}
\hline & \multicolumn{3}{|l|}{ Innovation-value fit } \\
\hline & Poor & Neutral & Good \\
\hline \multirow{2}{*}{$\begin{array}{l}\text { Strong } \\
\text { implementation } \\
\text { climate }\end{array}$} & $\begin{array}{l}\text { Employee opposition and } \\
\text { resistance }\end{array}$ & Employee indifference & Employee enthusiasm \\
\hline & $\begin{array}{l}\text { Compliant innovation use, at } \\
\text { best }\end{array}$ & Adequate innovation use & $\begin{array}{l}\text { Committed, consistent, and } \\
\text { creative innovation use }\end{array}$ \\
\hline \multirow{2}{*}{$\begin{array}{l}\text { Weak } \\
\text { implementation } \\
\text { climate }\end{array}$} & Employee relief & Employee disregard & $\begin{array}{l}\text { Employee frustration and } \\
\text { disappointment }\end{array}$ \\
\hline & Essentially no innovation use & Essentially no innovation use & $\begin{array}{l}\text { Sporadic and inadequate } \\
\text { innovation use }\end{array}$ \\
\hline
\end{tabular}

Source: Klein \& Sorra 1996:1066

Innovation implementation may therefore result in one of three outcomes (Klein \& Sorra 1996:1070):

- Implementation is effective, and use of the innovation enhances the organisation's performance the organisation's implementation climate is strengthened. Managers' and supervisors' support for innovation implementation increases, yielding likely improvements in implementation policies and practices

- Implementation is effective, but use of the innovation does not enhance the organisation's performance - the organisation's climate for implementation declines.

- Implementation fails - an implementation climate, which has in all likelihood always been weak, weakens further unless - in response to initial signs of implementation failure - managers demonstrably increase their support for innovation implementation by changing the organisation's implementation policies and practices to better support implementation.

\section{CONCLUSIONS}

- Entrepreneurial behaviour, or more specifically intrapreneurial orientation, was viewed as a strategic dimension on which all firms should take part. 
- The integration in the study between change management and strategic management, and between intrapreneurship and strategic management, filled a gap in existing literature (see, for example, Beer \& Eisenstat 1996:599).

- The emphasis on strategic implementation in this study addressed an issue that is considered one of the biggest reasons for failed strategies and abandoned planning efforts (Bourgeois \& Brodwin 1984).

- The proposed framework does not only touch on the harder elements in the implementation of strategies, for example the structures and systems, but also on the softer elements of skill, values and leadership - a prerequisite for effective implementation according to Beer \& Eisenstat (1996:599).

\section{RECOMMENDATIONS}

Future research into this topic could proceed along any number of important paths. Studies of the forms of entrepreneurial firm-level behaviour would certainly be useful in helping to define better the process and domain of entrepreneurship as they pertain to established organisations. As implied above, studies that seek to determine when and where an intrapreneurial orientation is appropriate would be particularly useful. No less significant would be research into the management of an intrapreneurial orientation. Finally, the proposed framework presents numerous specific relationships that are open to investigation. Hopefully, future researchers will find this a valuable conceptual framework that suggests promising research directions.

\section{BIBLIOGRAPHY}

AAKER DA. 1995. Developing business strategies. 4th ed. New York: Wiley.

BEER M \& EISENSTAT RA. 1996. Developing an organization capable of implementing strategy and learning. Human Relations, 49(5): 597-620, May.

BEER M, EISENSTAT RA \& SPECTOR B. 1990. Why change programs don't produce change. Harvard Business Review, 158-166, Nov.-Dec.

BOURGEOIS L \& BRODWIN D. 1984. Strategic implementation: five approaches to an elusive phenomenon. Strategic Management Journal, 5(3): 241-264.

BURGELMAN RA. 1983. Corporate entrepreneurship and strategic management: Insights from a process study. Management Science, 29(2): 1349-1364.

BURGELMAN RA. 1984. Designs for corporate entrepreneurship. California Management Review, 26(2): 154-166.

CORNWALL JR \& PERLMAN B. 1990. Organizational entrepreneurship. Homewood: Irwin.

COVIN JG \& SLEVIN DP. 1989. Strategic management of small firms in hostile and benign environments. Strategic Management Journal, 10(1): 75-87.

COVIN JG \& SLEVIN DP. 1991. A conceptual model of entrepreneurship as firm behaviour. Entrepreneurship Theory and Practice, 16(1): 7-25.

DRUCKER PF. 1994. The theory of business. Harvard Business Review, 95-104, September-October.

GINSBERG A. 1988. Measuring and modeling changes in strategy: theoretical foundations and empirical directions. Strategic Management Journal, 9: 559-575.

GUTH WD \& GINSBERG A. 1990. Guest editor's introduction: Corporate entrepreneurship. Strategic Management Journal (special issue) 11: 5-15.

HAMEL G \& PRAHALAD CK. 1989. Strategic intent. Harvard Business Review, 67: 63-76, May-June. 
HIGGINS JM. 1996. Achieving the core competence - It's as easy as 1,2,3, ... 47, 48, 49. Business Horizons, 39(2): 2732, March-April.

KWANDWALLA PN. 1977. The design of organizations. New York: Harcourt Brace Jovanovich.

KHANDWALLA PN. 1987. Generators of pioneering-innovative management: some Indian evidence. Organizational Studies, 8(1): 39-59.

KIRZNER IM. 1979. Perception, opportunity, and profit. Chicago: University of Chicago Press.

KLEIN KJ \& SORRA JS. 1996. The challenge of innovation implementation. Academy of Management Review, 21(4): 1055-1080.

LUMPKIN GT \& DESS GG. 1996. Clarifying the entrepreneurial orientation construct and linking it to performance. Academy of Management Review, 21(1): 135-173.

MASTENBROEK WFG. 1996. Organizational innovation in historical perspective: Change as duality management. Business Horizons, 39(4): 5-13, July-August.

MILES RE \& SNOW L. 1978. Organization, strategy, structure and process. New York : McGraw Hill.

PETERS T. 1995. Thinkers: Tom Peters. (In: Crainer S. ed. Financial Times Handbook of Management. London: Pitman.)

PETERS T \& WATERMAN R. 1982. In search of excellence. New York: Harper \& Row.

QUINN JB. 1979. Technological innovation, entrepreneurship and strategy. Sloan Management Review: 19-30, Spring.

QUINN JB. 1985. Managing innovation: Controlled chaos. Harvard Business Review, 63(3): 73-84.

REID, D. 1989. Operationalizing strategic planning. Strategic Management Journal, 10: 553-567.

ROWE AJ, MASON RO, DICKEL KE \& SNYDER NH. 1989. Strategic management: a methodological approach. Reading : Addison-Wesley.

SLATER S. 1989. The influence of managerial style on business unit performance. Journal of Management, 15: 441-455.

SMART DT \& CONANT JS. 1994. Entrepreneurial orientation, distinctive marketing competencies and organizational performance. Journal of Applied Business Research, 10(3): 28-38, Summer.

STEVENSON HH \& JARILLO JC. 1990. A paradigm of entrepreneurship: Entrepreneurial management. Strategic Management Journal, 11: 17-27, Summer.

STRUWIG FW. 1991. Intrapreneurship: a strategy for managing change and innovation. Port Elizabeth : Vista (DPhil thesis).

SYKES HB \& BLOCK Z. 1989. Corporate venturing obstacles. Journal of Business Venturing, 159-167, Winter.

THOMPSON AA, FULMER WE \& STRICKLAND AJ. 1992. Readings in strategic management. 4th ed. Boston: Irwin.

THOMPSON JL. 1990. Strategic management - awareness and change. London: Chapman \& Hall.

WALDERSEE R \& SHEATHER S. 1996. The effects of strategy type on strategy implementation actions. Human Relations, 49(1): 105-123, January.

WATERMAN R, PETERS T \& PHILLIPS JR. 1980. Organization is not structure. Business Horizons, 14-26, Jun.

WOOLRIDGE B \& FLOYD SW. 1990. Bridging the gap between strategy and operations: the implications of middle management involvement in strategy. Paper presented at the 10th Annual International Conference of the Strategic Management Society, Stockholm. 